\title{
A construção da religião como uma categoria antropológica
}

\author{
Talal Asad \\ tradução: Bruno Reinhardt e Eduardo Dullo
}

Em muito do pensamento evolucionário do século XIX, a religião era considerada uma condição humana primeira a partir da qual o direito, a ciência e a política modernos emergiram e se separaram ${ }^{1}$. Neste século, a maioria dos antropólogos abandonou as ideias evolucionárias Vitorianas, e muitos desafiaram a noçáo racionalista de que a religião é simplesmente uma forma primitiva e, portanto, ultrapassada das instituiçóes que hoje nós encontramos em sua forma verdadeira na vida moderna (direito, política, ciência). Para esses antropólogos do século $\mathrm{XX}$, a religião não é um modo arcaico do pensamento científico, nem de qualquer outra empreitada secular que nós valorizamos atualmente: ela é, ao contrário, um espaço distintivo da prática e da crença humanas que náo pode ser reduzido a nenhum outro. Disso parece seguir que a essência da religião não deve ser confundida com, digamos, a essência da política - embora em muitas sociedades as duas possam se sobrepor e se entrelaçar.

Com a sutileza que lhe é característica, Louis Dumont nos conta que a cristandade medieval foi uma sociedade compósita desse tipo:

Eu tomo como dado que uma mudança nas relaçóes implica uma mudança naquilo que está relacionado. Se ao longo de nossa história a religião impulsionou (em grande medida, havendo algumas outras influências em jogo) uma revolução nos valores sociais e deu à luz, como por cissiparidade, a um mundo autônomo de instituiçôes e especulações políticas, então, certamente, a própria religião terá se transformado nesse processo. Da existência de algumas mudanças importantes e visíveis, todos temos consciência, mas acredito que não estejamos conscientes das mudanças que afetaram a própria natureza da religião como ela é vivida por um indivíduo qualquer, digamos, por um católico. Todos sabem que a religião era, anteriormente, uma questão coletiva e que se tornou uma questão individual (em princípio, e também na prática, ao menos em vários ambientes e situaçóes). Mas se concluirmos que esta mudança está correlacionada com o nascimento do Estado moderno, não estamos mais no lugar-comum da proposiçáo anterior. Avancemos um pouco mais: a religiáo medieval foi um grande manto - penso aqui no manto de Nossa Senhora das Mercês. Uma vez que ela se tornou uma questão individual, perdeu sua capacidade totalizante e se tornou apenas um dentre outros fatores em aparente pé de igualdade, entre os quais o político foi o primeiro a nascer. Cada indivíduo pode, é claro, e talvez o faça, reconhecer na religião (ou na filosofia) a mesma capacidade totalizante com que antes ela era dotada socialmente. No entanto, no nível do consenso social ou da ideologia, a mesma pessoa migrará para uma configuração de valores distinta, na qual valores autônomos (religiosos, políticos, etc.) são aparentemente justapostos, assim como os indivíduos estão justapostos na sociedade. (Dumont, 1971, p. 32; ênfase no original).

cadernos de campo, São Paulo, n. 19, p. 1-384, 2010 
De acordo com essa visão, a religião medieval, mesmo infiltrando ou englobando outras categorias, ainda seria identificável analiticamente. É este fato que torna possível dizer que a religião teria hoje a mesma essência que tinha na Idade Média, apesar de que sua extensão e função sociais fossem diferentes nas duas épocas. A insistência na tese de que a religiáo teria uma essência autônoma - que não poderia ser confundida com a essência da ciência, da política ou do senso comum - convida-nos, contudo, a definir a religiáo (assim como qualquer essência) como um fenômeno trans-histórico e transcultural. Talvez seja uma feliz coincidência que esse esforço de definição da religiáo seja convergente com a exigência liberal de nossa época: que ela seja mantida bem separada da política, do direito e da ciência - espaços nos quais diversos poderes e razóes articulam nossa vida distintamente moderna. Essa definição é, ao mesmo tempo, parte de uma estratégia de confinamento (para os liberais seculares), e de defesa (para os cristãos liberais) da religião.

No entanto, essa separação entre religião e poder é uma norma Ocidental moderna, produto de uma singular história pós-Reforma. A tentativa de compreender tradiçóes muçulmanas insistindo em que nelas religiáo e política (duas essências que a sociedade moderna tenta manter conceitual e praticamente apartadas) estáo conectadas induz, na minha visão, necessariamente ao erro. Em sua forma mais dúbia, essas tentativas nos estimulam a assumir uma posição $a$ priori na qual os discursos religiosos na arena política são vistos como um disfarce para o poder político.

No que se segue, gostaria de examinar as maneiras como a busca teórica por uma essência da religiáo nos convida a separá-la conceitualmente do domínio do poder. Farei isto ao explorar a definição universalista de religiáo oferecida por um eminente antropólogo: "Religiâo como sistema cultural", de Clifford Geertz $^{2}$. Enfatizo que não se trata aqui primor- dialmente de uma revisão crítica das ideias de Geertz acerca da religiáo - se fosse este meu objetivo, teria me ocupado da totalidade de seus escritos sobre religião na Indonésia e no Marrocos. Minha intenção neste capítulo é tentar identificar algumas das alterações históricas envolvidas no processo de produçáo de nosso conceito de religiáo como o conceito de uma essência trans-histórica - e o artigo de Geertz servirá apenas como meu ponto de partida.

Faz parte do meu argumento básico que as formas, as pré-condiçóes e os efeitos socialmente identificáveis daquilo que era considerado religião durante a época cristã medieval eram muito diferentes dos [efeitos, pré-condições e formas] que são considerados religião na sociedade moderna. Quero chegar a este fato largamente reconhecido sem incorrer em mero nominalismo. Aquilo a que chamamos de poder religioso era distribuído de outra forma e tinha um ímpeto distinto. Eram diferentes as maneiras pelas quais esse poder criava e atravessava instituiçóes jurídicas; eram diferentes as subjetividades [selves] que ele formava e às quais se reportava; eram diferentes as categorias de conhecimento que ele autorizava e tornava disponível. Contudo, uma consequência é que aquilo com que o antropólogo se confronta não é apenas uma coleção arbitrária de elementos e processos que por acaso chamamos de "religiăo". Pois o fenômeno inteiro deve ser visto, em grande medida, no contexto das tentativas cristás de alcançar uma coerência em doutrinas e práticas, regras e regulamentos, mesmo que esta situação nunca tenha sido plenamente alcançada. $\mathrm{O}$ meu argumento é que não pode haver uma definição universal de religião, não apenas porque seus elementos constituintes e suas relações são historicamente específicos, mas porque esta definição é ela mesma o produto histórico de processos discursivos.

Uma definição universal (i.e., antropológica) é, no entanto, exatamente aquilo que Geertz pretende: uma religiāo, ele propõe, é 
(1) um sistema de símbolos que atua para (2) estabelecer poderosas, penetrantes e duradouras disposiçóes e motivações nos homens através da (3) formulação de conceitos de uma ordem de existência geral e (4) vestindo essas concepçóes com tal aura de factualidade que (5) as disposições e motivaçóes parecem singularmente realistas (Geertz, 1989, p. 67).

A seguir, examino esta definição não apenas com a finalidade de testar suas proposiçóes interconectadas, mas também para dar substância à alegação em contrário de que uma definição trans-histórica de religião não é viável.

\section{O conceito de símbolo como uma pista para a essência da religiáo}

Geertz percebe como sua primeira tarefa a definição do conceito de símbolo: "qualquer objeto, ato, acontecimento, qualidade ou relação que serve como vínculo a uma concepção - a concepção é o 'significado' do símbolo” (Geertz, 1989, p. 67-68). Mas esta afirmação clara e simples - na qual simbolo (qualquer objeto, etc.) é diferenciado de, mas conectado à concepção (seu significado) -, é posteriormente suplementada por outras que não são inteiramente consistentes com ela, pois o símbolo não é um objeto que serve como veículo para uma concepção: ele é a própria concepção. Assim, na afirmação "O número 6, escrito, imaginado, disposto numa fileira de pedras ou indicado num programa de computador, é um símbolo" (Geertz, 1989, p. 68), o que constitui todas essas diversas representações como versões do mesmo símbolo ("o número 6") é, claro, uma concepção. Ademais, Geertz parece sugerir em algumas ocasióes que, mesmo como uma concepção, um símbolo tem uma conexão intrínseca com eventos empíricos, dos quais ele é separável apenas "teoricamente": "a dimensão simbólica dos acontecimentos so- ciais é, como a psicológica, ela mesma abstraível a partir desses acontecimentos como totalidades empíricas" (Op. cit.). Em outras ocasiôes, entretanto, ele enfatiza a importância de se manterem símbolos e objetos empíricos bem separados: "é preciso dizer algo para não confundir nosso tráfico com os símbolos com nosso tráfico com objetos ou seres humanos, pois estes últimos não são símbolos eles mesmos, embora muitas vezes funcionem como tal" (Op. cit.). Com isso, "símbolo" é, às vezes, um aspecto da realidade e, em outras, de sua representação ${ }^{3}$.

Essas divergências são sintomas da mistura presente nesta narrativa entre questôes cognitivas e comunicativas; isso torna difícil investigar os modos com que discurso e compreensão são conectados nas práticas sociais. Para começar, podemos dizer, assim como vários outros autores o fizeram, que o símbolo não é um objeto ou evento que serve como veículo para um significado, mas um conjunto de relaçóes entre objetos ou eventos agregados singularmente como complexos ou conceitos ${ }^{4}$, tendo ao mesmo tempo significância intelectual, instrumental e emocional ${ }^{5}$. Se definirmos símbolo nessa linha ${ }^{6}$, uma série de questôes podem ser sugeridas no que tange às condiçóes que explicam como tais complexos e conceitos vieram a ser formados, e em particular como a sua formação se relaciona a uma variedade de práticas. Meio século atrás, Vygotsky já nos mostrara como o desenvolvimento do intelecto infantil depende da internalização da fala social ${ }^{7}$. Isso significa que a formação daquilo que chamamos, aqui, de "símbolos" (complexos, conceitos) é condicionada pelas relaçôes sociais com as quais a criança em crescimento se envolve - pelas atividades sociais que a ele ou a ela são permitidas, encorajadas, ou obrigadas a realizar - nas quais outros símbolos (fala e movimentos significativos) são cruciais. As condiçôes (discursivas e não discursivas) que explicam como símbolos vêm a ser construídos, e como alguns deles são estabele- 
cidos como naturais ou autoritativos ${ }^{8}$ em oposição a outros, tornam-se então objeto importante da investigaçáo antropológica. Deve-se destacar que náo se trata de defender o estudo da origem e função dos símbolos em acréscimo ao de seus significados - tal distinção é irrelevante aqui. $\mathrm{O}$ que se está argumentando é que o status autoritativo das representaçóes/discursos é dependente da produção adequada de outras representaçôes/ discursos; ambos estão intrinsecamente, e não apenas temporalmente conectados.

Sistemas de símbolos, afirma Geertz, são também padróes culturais, e constituem "fontes extrínsecas de informaçôes" (Op. cit.). Extrínsecas, porque "estão fora dos limites do organismo do indivíduo e, como tal, nesse mundo intersubjetivo de compreensóes comuns no qual nascem todos os indivíduos" (Op. cit.). E fontes de informação no sentido de que "eles fornecem um diagrama ou gabarito em termos do qual se pode dar forma definida a processos externos a eles mesmos" (Op. cit.). Portanto, nos é dito que padrôes culturais podem ser pensados como "modelos para a realidade" assim como "modelos de realidade".

Esta parte da discussão de fato abre possibilidades ao falar em modelamento, isto é, permite a possibilidade de conceituar discursos no processo de sua elaboração, modificação, teste, e assim por diante. Infelizmente, Geertz rapidamente regressa a sua posição anterior: "padróes culturais têm um aspecto duplo, intrínseco - eles dáo significado, isto é, uma forma conceptual objetiva, à realidade social e psicológica, modelando-se em conformidade a ela e ao mesmo tempo modelando-a a eles mesmos" (Op. cit.). Essa tendência supostamente dialética em direção ao isomorfismo acaba por tornar difícil o entendimento de como a mudança social pode vir a acontecer. O problema básico, no entanto, não está na ideia das imagens espelhadas em si, mas na suposição de que existem dois níveis separados em interação: o cultural, de um lado (consistindo em símbolos), e o social e psicológico, do outro. Esse recurso à teoria parsoniana cria um espaço lógico para definir a essência da religiăo. Ao adotar essa teoria, Geertz se distancia de uma noçáo de símbolos que são intrínsecos às práticas de organização e significação, e retorna a uma noção de símbolo como objetos que carregam significados, externos às condiçóes sociais e aos estados subjetivos [self] ("realidade social e psicológica").

Isso não implica dizer que Geertz não considera que os símbolos "fazem" algo. De um modo que lembra as abordagens antropológicas mais antigas sobre rituais ${ }^{10}$, ele afirma que os símbolos religiosos agem "induzindo o crente a um certo conjunto de disposiçôes (tendências, capacidades, propensôes, habilidades, hábitos, compromissos, inclinaçôes) que emprestam um caráter crônico ao fluxo de sua atividade e à qualidade da sua experiência” (Geertz, 1989, p. 70). Aqui, uma vez mais, símbolos são separados de estados mentais. Mas quão plausíveis são essas proposiçóes? Podemos, por exemplo, prever qual seria o conjunto de disposiçóes "distintivas" de um devoto cristão na sociedade industrial moderna? De modo alternativo, podemos dizer de alguém dotado de um conjunto de disposiçóes "distintivas" que ele é ou não é cristão? ${ }^{11}$ A resposta a ambas as interrogações certamente deve ser não. A razão, sem dúvida, é que não é apenas a devoção, mas as instituiçóes sociais, políticas e econômicas em geral ${ }^{12}$, no interior das quais as biografias individuais são vividas, que conferem estabilidade ao fluxo de atividades de um cristão e à qualidade de sua experiência.

Símbolos religiosos, Geertz elabora, produzem dois tipos de atitudes, disposiçôes e motivaçôes ${ }^{13}$ : "as motivaçôes são 'tornadas significativas' no que se refere aos fins para os quais são concebidas $\mathrm{e}$ conduzidas, enquanto as disposiçôes são 'tornadas significativas' no que diz respeito às condiçốes a partir das quais se concebe que elas surjam" (Geertz, 1989, p. 72). Agora, um Cristáo poderia dizer que esta não é sua essência, pois símbolos 
religiosos, mesmo quando falham em produzir disposiçóes e motivaçôes, permanecem símbolos religiosos (i.e., verdadeiros) - que símbolos religiosos possuem uma verdade independente de sua efetividade. Ainda assim, mesmo um cristáo comprometido náo pode deixar de se preocupar com a existência de símbolos verdadeiros que parecem ser amplamente impotentes na sociedade moderna. Ele desejará, com razão, perguntar: Quais são as condiçóes em que símbolos religiosos de fato podem produzir disposiçôes religiosas? $\mathrm{Ou}$, como diria alguém que não crê: como o poder (religioso) cria a verdade (religiosa)?

A relação entre poder e verdade é um tema antigo, e ninguém o abordou de forma mais impressionante no pensamento cristão do que Santo Agostinho. Agostinho desenvolveu sua visão sobre a função religiosa criativa do poder após sua experiência com a heresia donatista, insistindo que a coação seria uma condição para a realização da verdade, assim como a disciplina seria essencial para a sua manutenção:

Para um donatista, a postura de Agostinho frente à coação era uma negação flagrante dos ensinamentos cristáos tradicionais: Deus fizera os homens livres para escolherem entre o bem e o mal; uma política que forçasse essa escolha era claramente irreligiosa. Os autores donatistas citavam as mesmas passagens bíblicas que mais tarde seriam citadas por Pelágio em favor do livre-arbítrio. Ao retrucar a eles, Agostinho já lhes deu a mesma resposta que daria aos pelagianos: o ato individual e final de escolha devia ser espontâneo, mas esse ato de escolha podia ser preparado por um longo processo, que os homens não necessariamente escolhiam por si, mas que amiúde lhes era imposto por Deus, contra a sua vontade. Esse era um processo corretivo de 'ensinamento', eruditio, e admoestação, admonitio, que podia até mesmo incluir o medo, a coerçấo e a inconveniência externa: 'Que se encontre a coerção do lado de fora; é dentro que nasce a vontade'.
Agostinho convencera-se de que os homens precisavam desse manejo firme. Resumiu sua atitude numa palavra: disciplina. E não pensava nessa disciplina como muitos de seus contemporâneos romanos mais tradicionais, como a preservação estática de um 'estilo de vida romano'. Para ele, tratava-se de um processo essencialmente ativo de punição corretiva, um 'processo de abrandamento', uma 'instrução pelas inconveniências' - per molestias eruditio. No Velho Testamento, Deus ensinara Seu obstinado povo eleito justamente por esse processo de disciplina, contendo e unindo suas tendências malévolas com toda uma série de desgraças ditadas pela Providência. A perseguiçấo aos donatistas era mais uma 'catástrofe controlada' imposta por Deus, mediada, na ocasião, pelas leis dos imperadores cristáos. (...) A visão agostiniana da Queda da humanidade determinou sua atitude perante a sociedade. Os homens decaídos tinham passado a necessitar de contenção. Até as maiores realizações do homem só tinham sido possibilitadas pela 'camisa-de-força' da severidade incessante. Agostinho tinha um grande intelecto e um respeito saudável pelas conquistas da razão humana. No entanto, sentia-se obcecado com as dificuldades do pensamento e com os longos processos coercitivos, rememorativos dos horrores de seus próprios tempos de escola que haviam possibilitado essa atividade intelectual, tão 'propensa ao descanso' era a mente humana decaída. Ele dizia preferir a morte a voltar a ser criança. Não obstante, os terrores daquela época tinham sido rigorosamente necessários, pois faziam parte da assombrosa disciplina divina - 'desde a vergasta dos professores até as agonias dos mártires' - por intermédio da qual os seres humanos eram resgatados de suas inclinaçōes desastrosas pelo sofrimento (Brown, 2005, p. 294-296).

A fórmula de Geertz não é demasiadamente simples para acomodar a força deste simbolismo religioso? Note-se que aqui não são apenas 
os símbolos que implantam disposições verdadeiramente cristãs, mas o poder - que vai das leis (imperial e eclesiástica) e outras sanções (o fogo do inferno, a morte, a salvação, a boa reputação, a paz) às atividades disciplinares das instituições sociais (família, escola, cidade, igreja) e dos corpos humanos (jejum, prece, obediência, penitência). Para Agostinho era bastante claro que o poder, efeito de toda uma rede de práticas motivadas, assume uma forma religiosa em razão do fim a que se dirige, pois os eventos humanos são instrumentos de Deus. Não foi a mente que se moveu espontaneamente em direção à verdade religiosa; foi o poder que criou as condiçóes para que esta verdade fosse experimentada ${ }^{14}$. Os discursos e práticas particulares deveriam ser sistematicamente excluídos, proibidos, denunciados - tornados, tanto quanto possível, impensáveis; outros deveriam ser incluídos, permitidos, celebrados e inseridos na narrativa da verdade sagrada. Nesse sentido, as configuraçôes de poder têm certamente variado profundamente na cristandade de um período para o outro - dos tempos de Agostinho, passando pela Idade Média, até o atual Ocidente capitalista industrial. Os padróes religiosos de disposições e motivaçôes, bem como as possibilidades de conhecimento e verdade religiosa, têm variado e sido condicionados por esses fatores. Até Agostinho sustentara que, apesar de a verdade religiosa ser eterna, os meios para se assegurar o acesso humano a ela não o são.

\section{Da leitura de símbolos à análise de práticas}

Uma consequência de supor que existe um sistema simbólico separado das práticas é que distinçóes importantes são obscurecidas ou, até mesmo, explicitamente negadas. "Não deve causar qualquer surpresa o fato de que os símbolos ou sistemas de símbolos que induzem e definem as disposiçóes que estabelecemos como religiosas e aqueles que colocam essas disposiçóes num arcabouço cósmico são, na verdade, os mesmos símbolos" (Geertz, 1989, p. 72). Mas de fato isto surpreende! Vamos assumir que disposiçóes religiosas dependam crucialmente de certos símbolos religiosos, que tais símbolos operam de modo integral nas motivaçóes e disposiçóes religiosas. Mesmo assim, o processo simbólico através do qual os conceitos de motivaçôes religiosas e disposiçóes religiosas são inseridos em "um arcabouço cósmico" é certamente uma operação bastante distinta, e portanto, os signos envolvidos são bastante distintos. Colocado de outro modo, o discurso teológico não é idêntico nem a atitudes morais, nem a discursos litúrgicos - a respeito dos quais, entre outras coisas, a teologia se pronuncia $^{15}$. Cristãos cuidadosos admitiriam que, apesar da teologia ter uma funçáo essencial, o discurso teológico não necessariamente induz disposiçôes religiosas, e que, inversamente, ter disposiçóes religiosas não necessariamente depende de uma concepção cristalina do arcabouço cósmico por parte do ator religioso. Discurso envolvido em prática não se confunde com discurso envolvido em falar sobre a prática. É uma ideia moderna a de que um praticante náo sabe como viver religiosamente sem ser capaz de articular esse saber.

A razão pela qual Geertz mistura os dois tipos de processo discursivo parece resultar de um desejo de distinguir entre disposiçóes seculares e religiosas. A afirmação citada acima é elaborada do seguinte modo:

Do contrário, o que poderia significar dizermos que uma disposiçáa particular de temor é religiosa e não secular, a não ser que ela surge de uma concepção totalmente impregnada de vitalidade, como a do mana, e nâo de uma visita ao Grand Canyon? Ou que um caso particular de ascetismo é exemplo de motivação religiosa, a não ser que ele se propóe a realizar um fim incondicional como o nirvana, e não um fim condicio- 
nado como a redução do peso? Se os símbolos sagrados não induzissem a disposiçôes nos seres humanos e ao mesmo tempo não formulassem idéias gerais de ordem, (...) então não existiria a diferenciação empírica da atividade religiosa ou da experiência religiosa (Op. cit.).

$\mathrm{O}$ argumento de que uma disposição particular é religiosa em parte porque ela ocupa um lugar conceitual no interior de um arcabouço cósmico parece plausível, mas apenas porque ela pressupóe uma questão que deve ser explicitada: como os processos autoritativos representam práticas, enunciados ou disposiçóes de modo a poderem ser relacionados discursivamente a ideias gerais (cósmicas) sobre a ordem? Em suma, a questão pertence ao processo autoritativo através do qual a "religião" é criada.

Os modos como os discursos autoritativos, ao pressupor e expor uma cosmologia, sistematicamente redefiniram os espaços religiosos foram de profunda importância na história da sociedade Ocidental. Na Idade Média, tais discursos abarcavam um amplo domínio, definindo e criando a religião: ao rejeitar práticas 'pagãa' ou aceitá-las ${ }^{16}$; ao autenticar milagres e relíquias particulares (os primeiros confirmando as segundas e vice-versa) ${ }^{17}$; ao certificar santuários ${ }^{18}$; ao compilar a vida dos santos de modo a fornecer um modelo de e para a Verdade ${ }^{19}$; ao exigir a confissão dos pensamentos, palavras e feitos pecaminosos a um padre confessor e conceder absolvição a um penitente ${ }^{20}$; ao regulamentar os movimentos sociais populares em termos de Ordens regidas por certas Regras (por exemplo, os franciscanos), ou ao denunciá-los por heresia ou por resvalarem o herético (por exemplo, as beguinas) ${ }^{21}$. A Igreja medieval não procurou estabelecer a uniformidade absoluta das práticas; pelo contrário, seu discurso autoritativo sempre se preocupou em especificar diferenças, gradaçôes, exceçóes. O que ela buscava era a sujeição de toda prática a uma autoridade unificada, a uma fonte autêntica e única que pudesse distinguir a verdade da falsidade. Foram os antigos Pais da Igreja que estabeleceram o princípio de que apenas uma Igreja unificada poderia se tornar a fonte do discurso autenticador ${ }^{22}$. Eles sabiam que os "símbolos" incorporados na prática dos cristáos autoconfessados nem sempre coincidem com a teoria da "Igreja única e verdadeira”, que a religião exige uma prática autorizada e uma doutrina autoritativa, e que sempre há uma tensão entre elas - às vezes irrompendo em heresia, a subversão da Verdade - o que tende a sublinhar o papel criativo do poder institucional ${ }^{23}$.

A Igreja medieval sempre foi clara sobre o motivo da necessidade contínua de distinguir o conhecimento da falsidade (a religião daquilo que procurava subvertê-la), assim como o sagrado do profano (a religião daquilo que estava fora dela), distinçôes cuja prova derradeira eram os discursos autoritativos, os ensinamentos e práticas da Igreja, e não as convicçôes do praticante ${ }^{24}$. Inúmeras vezes antes da Reforma, a fronteira entre o religioso e o secular foi redesenhada; mas a autoridade formal da Igreja permaneceu sempre preeminente. Nos séculos seguintes, com o surgimento triunfal da ciência moderna, do modo moderno de produção e do Estado moderno, as igrejas elas mesmas assumem uma posiçấo clara acerca da necessidade de se distinguir o religioso do secular, transferindo, como de fato o fizeram, o peso da religiáo cada vez mais na direçâo das disposiçôes e motivaçôes do indivíduo crente. A disciplina (intelectual e social) iria, nesse período, gradualmente abandonar o espaço religioso, cedendo seu lugar à "crença", à "consciência" e à "sensibilidade" 25 . Mas a teoria ainda seria necessária para definir a religião.

\section{A construção da religiáo no início da Modernidade europeia}

As primeiras tentativas sistemáticas de produzir uma definição universal da religião foram 
feitas no século XVII, após a fragmentação da unidade e da autoridade da Igreja de Roma e as consequentes guerras religiosas que dividiram os principados europeus. Um passo significativo na história dessa definição foi o De veritate de Herbert. "Lord Herbert", segundo Willey,

difere de outros homens como Baxter, Cromwell ou Jeremy Taylor principalmente porque, não satisfeito com a redução do credo a um número mínimo possível de fundamentos, ele regressa em relação ao Cristianismo ele mesmo, indo à busca de uma crença que deveria reger o consentimento universal de todos os homens enquanto homens. Deve ser lembrado que aquela antiga situação, simples, na qual a cristandade se autorepresentava como o mundo, apenas com os abomináveis pagãos do lado de fora e os judeus nos portóes, já havia acabado para sempre. A exploração e o comércio haviam ampliado o horizonte e em muitos autores do século pode-se perceber que as religióes do Oriente, ainda que imperfeitamente conhecidas, começavam a pressionar as consciências. Foi o interesse pioneiro nessas religióes, juntamente com a costumeira preocupação dos eruditos da Renascença com a mitologia clássica, que levou Lord Herbert a buscar um denominador comum para todas as religióes e, assim, promover (ou assim ele esperava) a muito necessária eirenicon para as disputas do século XVII (1934, p. 114).

Assim, Herbert produziu uma definição substantiva do que depois veio a ser formulado como Religião Natural - em termos de crenças (em um poder supremo), práticas (sua devoção organizada) e ética (um código de conduta baseado em recompensas e puniçóes após esta vida) -, sobre a qual se dizia existir em todas as sociedades $^{26}$. Essa ênfase na crença queria dizer que, dali em diante, a religiáo poderia ser concebida como um conjunto de proposiçóes para as quais os fiéis davam seu consentimento e que poderia, portanto, ser julgada e comparada, como uma dentre as diferentes religióes e em contraposição às ciências naturais (Harrison, 1990).

A ideia de Escritura (um texto divinamente produzido/interpretado) não era essencial a esse "denominador comum" das religiōes, parcialmente porque os cristãos já haviam se familiarizado mais com sociedades sem escrita através das redes comerciais e da colonização. Mas uma razão ainda mais importante se encontra na mudança de atençáo, que ocorreu ao longo do século XVII, das palavras de Deus aos trabalhos de Deus. A "Natureza” tornou-se o verdadeiro espaço da escrita divina e, em algum momento, a autoridade inconteste à qual deve ser submeter a verdade de todos os textos sagrados, escritos com linguagem meramente humana (Velho e Novo Testamentos). Assim:

O texto de Locke A Razoabilidade [Reasonableness] do Cristianismo popularizou uma nova versão do cristianismo ao reduzir sua doutrina ao menor denominador comum: a crença em Jesus como Messias, cujo advento havia sido narrado pelas profecias do Velho Testamento. Mesmo esse credo reduzido deveria ser medido em contraposição à Religiáo Natural e à Religiáo da Ciência Natural, de modo que a Revelação, além de ter de se justificar com base no padrão de Locke, também teria de se apresentar como uma reiteração da Religiáo Natural. Por algum tempo, de fato, a Palavra de Deus assumiu uma posição secundária em relação às suas obras, iniciadas no momento da criaçáo do universo. Pois, enquanto o testemunho das últimas era universal e ubíquo, a evidência da Revelação se limitava a livros sagrados escritos em línguas mortas, cuja interpretação não gerava consenso nem mesmo entre os cristãos confessos, além de estar relacionada a eventos distantes, que haviam ocorrido em tempos remotos, apartados dos centros de conhecimento e civilizaçáo (Sykes, 1975, p. 195-96). 
Desse modo, a Religião Natural não só se tornou um fenômeno universal, como começou a ser diferenciada do domínio emergente da ciência natural e a corroborá-lo. Gostaria de enfatizar que a ideia de Religiâo Natural foi um passo crucial na formação do conceito moderno de crença, experiência e prática religiosas, e que foi uma ideia desenvolvida em resposta a problemas específicos da teologia cristã numa conjunção histórica particular.

Em 1795, Kant foi capaz de produzir uma ideia de religião plenamente essencializada, que poderia ser contraposta a suas formas fenomênicas: "Pode, sem dúvida, haver diferentes tipos de fe"

que não radicam na religião, mas na história dos meios utilizados para o seu fomento, pertencentes ao campo da erudição; e pode igualmente haver diferentes livros religiosos (Zendavesta, Veda, Corão, etc.); mas só pode existir uma única religião válida para todos os homens e em todos os tempos. Por conseguinte, as crenças apenas contêm o veículo da religião, que é acidental e pode variar segundo os tempos e os lugares. (Kant, 2009).

Deste ponto em diante, a classificação das confissões históricas em termos de religióes mais ou menos elevadas tornou-se uma opção cada vez mais popular para filósofos, teólogos, missionários e antropólogos nos séculos XIX e XX. A existência de tribos particulares que não tivessem desenvolvido nenhuma forma de religião era frequentemente sugerida, mas como uma questáo reconhecidamente empírica ${ }^{27}$, que não afetava a essência da religião ela mesma.

Assim, o que aparece aos antropólogos de hoje como auto-evidente, isto é, que a religião é essencialmente uma questão de significados simbólicos ligados a ideias de ordem geral (expressos através de ritos e/ou doutrinas), que ela tem funçôes/características genéricas, e que ela não deve ser confundida com nenhuma outra de suas formas históricas ou culturais particulares, é de fato uma visão que tem uma história cristã específica. De um conjunto concreto de regras práticas ancoradas em processos específicos de poder e conhecimento, a religião se tornou abstraída e universalizada ${ }^{28}$. Neste movimento, não há um mero aumento da tolerância religiosa, nem, certamente, apenas uma nova descoberta científica, mas a modificação de um conceito e uma série de práticas sociais que é, ela mesma, parte de uma mudança mais ampla na paisagem moderna do poder e do conhecimento. Essa alteração incluiu um novo tipo de Estado, um novo tipo de ciência e um novo tipo de sujeito jurídico e moral. Para compreender essa modificação é essencial manter claramente distinto aquilo que a teologia tende a obscurecer: a ocorrência de eventos (enunciados, práticas, disposiçôes) e os processos autoritativos que dáo sentido a esses eventos e incorporam esse sentido em instituiçóes concretas.

\section{Religiáo enquanto significado e os significados religiosos}

A equação entre dois níveis de discurso (símbolos que induzem disposiçốes e outros que inserem tais disposiçóes discursivamente em um arcabouço cósmico) não é o único aspecto problemático dessa parte do argumento de Geertz. Ele também parece assumir, inadvertidamente, o ponto de vista da teologia. Isto acontece quando Geertz insiste na primazia do significado em detrimento dos processos através dos quais os significados são construídos.

O que qualquer religião particular afirma a respeito da natureza fundamental da realidade pode ser obscuro, superficial ou, o que acontece muitas vezes, perverso; mas ela precisa afirmar alguma coisa, se não quiser consistir apenas em uma coletânea de práticas estabelecidas e sentimentos

cadernos de campo, São Paulo, n. 19, p. 263-284, 2010 
272 TAlal Asad

convencionais aos quais habitualmente nos referimos como moralismo (Geertz, 1989, p. 73).

As linhas mestras da afirmação anterior são aparentemente inocentes e lógicas. No entanto, através delas todo o campo da atividade evangelizadora foi historicamente aberto, em particular a ação dos missionários europeus na Ásia, África e América Latina. A exigência de que práticas reconhecidas devam afirmar algo sobre a natureza fundamental da realidade, e que portanto, seja possível atribuir a elas significados que não sejam absurdos, é a primeira condição para determinar se estas pertencem à "religião". O não evangelizado vem a ser visto habitualmente como alguém que tem práticas mas que não afirma nada, permitindo que significados possam ser atribuídos às suas práticas (portanto, fazendo-os vulneráveis), ou, como aquele que de fato afirma algo (provavelmente "obscuro, superficial ou perverso"), uma afirmação que em última instância pode ser dispensada. No primeiro caso, uma teoria da religiáo torna-se necessária para a leitura correta dos hieróglifos rituais mudos dos outros, para reduzir suas práticas a textos; noutro caso, ela se torna essencial para julgar a validade de suas enunciaçôes cosmológicas. Mas sempre deve haver algo que existe para além das práticas observáveis, das enunciações ouvidas, das palavras escritas, e é função das teorias da religião alcançar e explicitar este pano de fundo ao dotá-lo de significado ${ }^{29}$.

Geertz está correto, portanto, ao fazer conexôes entre a teoria religiosa e a prática da religiáo, mas está errado ao vê-la como essencialmente cognitiva, como um meio através do qual uma mente sem corpo torna-se apta a identificar a religiáo a partir de um ponto de vista arquimediano. A relaçáo entre a teoria religiosa e a prática da religião é fundamentalmente um problema de intervenção - de construir a religião no mundo (e não na mente) através de discursos definidores, interpretando sentidos verdadeiros, excluindo algumas enunciaçôes e práticas e incluindo outras.
Logo, minha recorrente interrogação: como o discurso teórico define, de fato, a religião? Quais são as condiçóes históricas que lhe permitem agir efetivamente enquanto uma demanda pela imitação, a proibição ou a autenticação de enunciações e práticas? Como o poder cria a religião?

Quais tipos de afirmação, de significado, devem ser identificados a uma prática de modo que ela seja qualificada como religião? De acordo com Geertz, é porque todo ser humano tem profunda necessidade de uma ordem geral de existência que os símbolos religiosos funcionam para satisfazer essa necessidade. Conclui-se que os seres humanos têm um pavor profundo da desordem.

Há pelo menos três pontos nos quais o caos um tumulto de acontecimentos ao qual faltam não apenas interpretaçóes, mas interpretabilidade - ameaça o homem: nos limites de sua capacidade analítica, nos limites de seu poder de suportar e nos limites de sua introspecção moral (Geertz, 1989, p. 73).

É função dos símbolos religiosos lidar com ameaças à ordem percebidas em cada uma dessas dimensões (intelectual, física e moral):

O Problema do Significado em cada um dos seus aspectos de transição (...) é matéria para afirmar, ou pelo menos reconhecer, a inescapabilidade da ignorância, da dor e da injustiça no plano humano enquanto nega, simultaneamente, que essas irracionalidades sejam características do mundo como um todo. E é justamente em termos de um simbolismo religioso, um simbolismo que relaciona a esfera da existência do homem a uma esfera mais ampla dentro da qual se concebe que ele repouse, que tanto a afirmaçáo como a negação são feitas (Geertz, 1989, p. 80).

Notem como o raciocínio agora parece ter mudado suas bases de uma defesa de que a religião 
deve afirmar algo específico acerca da natureza da realidade (ainda que obscuro, raso, ou perverso) para uma sugestão insípida que a religião é, em última instância, uma questão de como cultivar uma atitude positiva em relação ao problema da desordem, de afirmar simplesmente que, em um ou em outro sentido, o mundo como um todo é explicável, justificável, suportável ${ }^{30}$. Essa visão modesta da religiāo (que teria horrorizado os Pais Apostólicos ou os homens da igreja medieval) ${ }^{31}$ é produto do único espaço legítimo permitido ao cristianismo pela sociedade pós-iluminista, o direito à crença individual. A condição humana é cheia de ignorância, dor e injustiça, e os símbolos religiosos são um meio para encarar essa condição de forma positiva. Uma consequência é que esta visão, a princípio, tomaria qualquer filosofia que realizasse tal função como religião (para o incômodo dos racionalistas do século XIX), ou alternativamente, tornar possível pensar a religião como algo mais primitivo, um esforço pouco adulto de se vir a termos com a condição humana (para incômodo do cristão moderno). Em ambos os casos, a sugestão de que a religiáo tem uma função universal na crença é uma indicação de quão marginal a religião teria se tornado na sociedade moderna industrial enquanto espaço para a produção de conhecimento disciplinado e disciplina pessoal. Por si só, ela começa a se parecer com a concepção que Marx tinha da religiáo como ideologia - ou seja, um modo de consciência que é outro que não a consciência da realidade, que é externo às relaçóes de produção, que não produz conhecimento, mas que expressa simultaneamente as angústias dos oprimidos e seu espúrio consolo.

No entanto, Geertz tem muito mais a dizer acerca da fugidia questáo do significado religioso: os símbolos religiosos não apenas formulam concepçóes sobre uma ordem geral da existência; eles também investem essas concepçóes de uma aura de factualidade. Este, nos dizem, é "o problema da crença”. A crença religiosa sempre envolve "uma aceitação prévia da autoridade" que transforma a experiência:

A existência da perplexidade, da dor e do paradoxo moral - do Problema do Significado é uma das coisas que impulsionam os homens para a crença em deuses, demônios, espíritos, princípios totêmicos ou a eficácia espiritual do canibalismo (...), mas essa não é a base onde repousam tais crenças, e sim seu campo de aplicação mais importante (Op. cit.).

Esta posição parece assumir que crenças religiosas existem de modo independente das condições mundanas que produzem perplexidade, dor e paradoxo moral, mesmo que a crença seja primariamente um modo de vir a termos com elas. Mas isto é certamente um erro, tanto a partir da lógica quanto da história, já que as mudanças no objeto da crença mudam essa crença; e enquanto o mundo muda, assim o fazem os objetos da crença e as formas específicas de perplexidade e paradoxo moral pertencentes a este mundo. Aquilo em que o cristão acredita hoje sobre Deus, vida após a morte e o universo, não é aquilo em que ele acreditava há um milênio - tampouco é igual a maneira como ele responde à ignorância, dor e injustiça hoje e naquele tempo. A valorização medieval da dor como modo de participação no sofrimento de Cristo contrasta radicalmente com a percepção católica moderna da dor como um mal a ser combatido e superado, assim como Cristo, aquele que Cura, o fez. A diferença está claramente conectada à secularização pós-iluminista da sociedade Ocidental e à linguagem moral que esta sociedade agora autoriza ${ }^{32}$.

O tratamento de Geertz da crença religiosa, que se encontra no âmago de sua concepção de religião, é um modo cristão privatizado e moderno, na medida em que ele enfatiza a prioridade da crença enquanto um estado mental ao invés de uma atividade constitutiva no mundo: "O 
axioma básico subjacente naquilo que poderíamos talvez chamar de 'perspectiva religiosa' é o mesmo em todo lugar: aquele que tiver de saber precisa primeiro acreditar" (Geertz, 1989, p. 81). $\mathrm{Na}$ sociedade moderna, na qual o conhecimento está enraizado ou em uma vida cotidiana não cristã, ou em uma ciência não-religiosa, o apologista cristáo tende a conceber a crença náo como a conclusão de um processo cognitivo, mas como sua pré-condição. No entanto, o conhecimento que ele promete nunca passará (nem ele afirma, com sinceridade, que um dia passará) por conhecimento da vida social, e menos ainda por conhecimento sistemático dos objetos que a ciência natural fornece. Sua reivindicação refere-se a um estado mental particular, um senso de convicção, e não a um corpo de saberes práticos. Mas a reversão da crença e do conhecimento que ela exige não era um axioma básico para, digamos, um cristão piedoso e cultivado do século XII, para quem conhecimento e crença não estavam tão claramente em conflito. Ao contrário, a crença cristã teria, então, de ser construída com base no conhecimento - conhecimento da doutrina teológica, da lei canônica e das cortes da Igreja, dos detalhes das liberdades clericais, dos poderes dos cargos eclesiásticos (sobre as almas, os corpos, as propriedades), das precondiçóes e efeitos da confissão, das regras das ordens religiosas, das localizaçôes e virtudes dos santuários, das vidas dos santos, e assim por diante. A familiaridade com estes conhecimentos (religiosos) foi uma precondição para uma vida social normal, e a crença (incorporada na prática e no discurso) uma orientação para a atividade efetiva nela - seja da parte do clero religioso, do clero secular ou do laicato. Por causa disso, a forma, textura e função dessas crenças seriam diferentes das formas, texturas e funçóes da crença contemporânea - o mesmo se estendendo às formas contemporâneas de dúvida e descrença.

A suposição de que a crença é um estado mental distinto presente em todas as religióes tem sido tema de discussão acadêmica contemporânea. Needham (1972) argumentou de modo interessante que a crença não é, sob nenhuma condição, um modo distinto de consciência, nem uma instituição necessária para a condução da vida social. Southwold (1979) assume uma postura quase diametralmente oposta, afirmando que questóes relativas à crença de fato se referem a estados mentais distintos e são relevantes em toda e qualquer sociedade, já que "acreditar" sempre designa uma relação entre o crente e uma proposição e, através desta, uma realidade. Harré (1981, p. 82), em uma crítica a Needham, faz uma defesa mais persuasiva da tese de que "a crença é um estado mental, uma disposição enraizada, mas que se confina a povos com certas instituiçóes e práticas sociais".

A todo custo, penso que náo é imprudente argumentar que "o axioma básico" subjacente ao que Geertz chama de "a perspectiva religiosa" não é o mesmo em toda parte. A igreja cristã é que tem primordialmente se ocupado em identificar, cultivar e testar a crença enquanto uma condição interna verbalizável da religião verdadeira ${ }^{33}$.

\section{A religiáo como perspectiva}

O vocabulário fenomenológico que Geertz emprega levanta duas questóes interessantes: uma se refere a sua coerência e outra, a sua adequação à moderna noção cognitivista de religiáo. Gostaria de sugerir que apesar de este vocabulário ser teoricamente incoerente, socialmente ele seria bastante compatível com a ideia privatizada de religiáo na sociedade moderna.

Assim, dizem-nos que a "perspectiva religiosa" é uma entre muitas outras - a científica, a estética e a do senso comum - e difere destas do seguinte modo. Difere da perspectiva do senso comum porque "se move além das realidades da vida cotidiana em direção a outras mais amplas, que as corrigem e completam, e 
sua preocupação definidora não é a ação sobre essas realidades mais amplas, mas sua aceitação, a fé nelas" (Geertz, 1989. p. 82). É diferente da perspectiva cientifica porque "questiona as realidades da vida cotidiana não a partir de um ceticismo institucionalizado que dissolve o 'dado' do mundo numa espiral de hipóteses probabilísticas, mas em termos do que é necessário para torná-las verdades mais amplas, não-hipotéticas" (Op. cit.). E ela se distingue da perspectiva estética porque "em vez de afastar-se de toda a questão da fatualidade, manufaturando deliberadamente um ar de parecença e de ilusão, ela aprofunda a preocupação com o fato e procura criar uma aura de atualidade real" (Op. cit.). Em outras palavras, apesar de a perspectiva religiosa não ser exatamente racional, ela também não é irracional.

Não seria difícil expressar uma discordância com esse resumo sobre os assuntos de que tratam o senso comum, a ciência e a estética ${ }^{34}$. Mas meu argumento aqui é que o sabor opcional exprimido pelo termo perspectiva é certamente enganador quando aplicado igualmente à ciência $\mathrm{e}$ à religiấo na sociedade moderna: a religião é, de fato, hoje, opcional de um modo que a ciência não é. Práticas científicas, técnicas, conhecimentos, permeiam e criam as fibras da vida social de um modo que a religiẫo não mais pode igua$\operatorname{lar}^{35}$. Nesse sentido, a religião hoje é uma perspectiva (ou uma "atitude", como Geertz a chama às vezes), mas a ciência não o é. E nesse mesmo sentido, a ciência não é encontrada em qualquer sociedade, passada e presente. Veremos em breve as dificuldades em que o perspectivismo de Geertz o coloca, mas antes disso eu preciso examinar sua análise da mecânica de manutenção da realidade em funcionamento na religião.

É coerente com os argumentos anteriores sobre as funções dos símbolos religiosos o comentário de Geertz de que "é no ritual - isto é, no comportamento consagrado - que se origina, de alguma forma, essa convicção de que as concepções religiosas são verídicas e de que as diretivas religiosas são corretas" (Op. cit.). A longa passagem de onde esta citação foi retirada oscila entre especulaçóes arbitrárias sobre o que acontece na consciência daqueles que conduzem cerimônias religiosas e afirmaçôes infundadas sobre o ritual enquanto inscrição. À primeira vista, esta parece ser uma curiosa combinaçáo de psicologia introspeccionista e behaviorista - mas como Vigotsky (1978, p. 58-59) argumentou há muito tempo, as duas não são, de maneira alguma, incompatíveis, na medida em que ambas supóem que os fenômenos psicológicos consistem essencialmente na consequência de vários ambientes estimulantes.

Geertz postula a função ocupada pelos rituais na geração de convicção religiosa ("É nesses dramas plásticos que os homens atingem sua fé, na medida em que a retratam" (Geertz, 1989, p. 83), mas como ou por que isso acontece não é explicado em lugar algum. De fato, ele admite que tal estado religioso não é sempre alcançado no ritual religioso: "É claro que nem todas as realizaçôes culturais são realizaçóes religiosas e a linha entre as que o são e as realizaçôes artísticas, ou até mesmo políticas, não é muito fácil de demarcar na prática, pois, como as formas sociais, as formas simbólicas podem servir a múltiplos propósitos" (Op. cit.). Mas a questáo permanece: o que é que garante que os participantes tomem as formas simbólicas de um modo que os conduza à fé se a linha que separa o religioso e o não religioso não é facilmente traçada? A habilidade e a vontade de se adotar uma perspectiva religiosa não deveria estar presente antes da performance do ritual? É precisamente este o motivo do náo funcionamento do modelo estímulo-resposta de analise de rituais. $\mathrm{E}$ se este for o caso, o ritual, no sentido da performance sagrada, não pode ser o lugar onde a fé religiosa é alcançada, mas a maneira como ela é (literalmente) atuada. Se quisermos compreender como isso ocorre, devemos examinar náo apenas a performance sagrada em si, mas também toda 
a gama de atividades disciplinares disponíveis, de formas institucionais de conhecimento e prática, em cujo âmbito as disposiçóes são formadas e mantidas e através das quais as possibilidades de alcançar a verdade são demarcadas - como Agostinho claramente observou.

Notei mais de uma vez a preocupaçáo de Geertz em definir os símbolos religiosos de acordo com critérios cognitivos e universais, para distinguir claramente a perspectiva religiosa das náo religiosas. A separação entre religião e ciência, senso comum, estética, política, e assim por diante, permite-lhe defendê-la das acusaçóes de irracionalidade. Se a religiâo tem uma perspectiva específica (sua própria verdade, como Durkheim teria dito) e realiza uma função indispensável, ela não compete, em essência, com outras esferas e não pode, portanto, ser acusada de gerar falsa consciência. No entanto, de certo modo esta defesa é equivocada. Geertz observa que os símbolos religiosos criam disposiçóes que parecem singularmente realistas. Este é o ponto de vista do agente relativamente confiante (que deve operar sempre no interior da densidade das probabilidades historicamente dadas) ou de um observador cético (que pode ver, através das representaçóes da realidade, a própria realidade)? Isto nunca fica claro. E nunca fica claro porque esse tipo de abordagem fenomenológica não permite examinar se, e em caso positivo, em que medida e de que modo, a experiência religiosa se relaciona a algo localizado no mundo real habitado pelos indivíduos que crêem. Isso acontece, em parte, porque os símbolos religiosos são tratados, de modo circular, como precondiçáo para a experiência religiosa (que como qualquer experiência deve, por definição, ser genuína), ao invés de uma condição para se engajar com a vida.

Perto do fim de seu ensaio, Geertz tenta conectar, ao invés de separar, a perspectiva religiosa com a do senso comum, e o resultado revela a ambiguidade básica de toda sua abordagem. Primeiramente, invocando Schutz, Geertz declara que o mundo quotidiano dos objetos do senso comum e dos atos práticos é compartilhado por todos os seres humanos, pois sua sobrevivência depende disso: "Um homem, até mesmo grandes grupos de homens, pode ser esteticamente insensível, não preocupado religiosamente e náo equipado para perseguir a análise científica formal, mas não pode ter uma falta total de senso comum, e assim mesmo sobreviver" (Geertz, 1989, p. 87). A seguir, ele nos informa que os indivíduos se encontram em um "movimento de ida e volta entre a perspectiva religiosa e a perspectiva do senso comum" (Op. cit.). Tais perspectivas são tão obviamente diferentes, ele declara, que apenas "saltos kierkegaardianos" (Geertz, 1989, p. 88) poderiam preencher as lacunas culturais que os separam. Logo, a seguinte conclusão fenomenológica:

Tendo "pulado" ritualmente (...) para o arcabouço de significados que as concepçóes religiosas definem e, quando termina o ritual, voltado novamente para o mundo do senso comum, um homem se modifica - a menos que, como acontece algumas vezes, a experiência deixe de ter influência. À medida que o homem muda, muda também o mundo do senso comum, pois ele é visto agora como uma forma parcial de uma realidade mais ampla que o corrige e o completa (Geertz, 1989, p. 89, ênfase adicionada).

Este curioso relato acerca de perspectivas alternantes e mundos em mudança gera confusáo - como de fato é no trabalho de Schutz. Não fica claro, por exemplo, se o arcabouço religioso e o mundo do senso comum, entre os quais o indivíduo se move, são independentes do indivíduo ou não. Muito do que Geertz havia dito no início de seu ensaio implicaria assumir que religiáo e senso comum são independentes (Geertz, 1989, p. 68), e seu comentário sobre o senso comum como sendo uma instância vital para a sobrevivência de qualquer homem também reforça essa leitura. No entanto, é também sugerido que 
quando o indivíduo crente muda de perspectiva, ele muda a si mesmo; e, ao mudar, seu mundo do senso comum também muda e é corrigido. Neste caso, a última mudança não é independente, de maneira alguma, dos movimentos do indivíduo. Mas, a partir desse relato, pareceria que o mundo religioso $e ́$ independente, já que ele é a fonte de uma experiência específica para aquele que crê e, através dessa experiência, uma fonte de mudança no mundo do senso comum: não há nenhuma sugestáo de que o mundo (ou a perspectiva) religioso(a) é de algum modo afetado(a) pela experiência no mundo do senso comum.

Este último aspecto é coerente com a abordagem fenomenológica, na qual os símbolos religiosos são sui generis, demarcando um domínio religioso independente. Mas no contexto corrente ele apresenta ao leitor um paradoxo: o mundo do senso comum é sempre comum a todos os seres humanos e bastante distinto do mundo religioso, que por sua vez difere de um grupo para outro, assim como as culturas diferem entre si; mas a experiência do mundo religioso afeta o mundo do senso comum e, entáo, a especificidade de cada um desses dois mundos é modificada, e o mundo do senso comum vem a ser diferente de um grupo para outro, assim como uma cultura difere de outra. Esse paradoxo é o resultado de uma fenomenologia ambígua, na qual a realidade é ao mesmo tempo a distância entre a perspectiva de um agente social e a verdade (mensurável apenas por um observador privilegiado) e também o conhecimento substancial de um mundo socialmente construído disponível tanto para o agente quanto para o observador, mas que para o último o é apenas através do primeiro ${ }^{36}$.

\section{Conclusão}

Talvez possamos aprender algo com este paradoxo, que nos ajudará a avaliar a conclusão confiante de Geertz:,
O estudo antropológico da religião é, portanto, uma operação em dois estágios: no primeiro, uma análise do sistema de significados incorporado nos símbolos que formam a religião propriamente dita e, no segundo o relacionamento desses sistemas aos processos sócio-estruturais e psicológicos (Geertz, 1989, p. 91, ênfase adicionada).

Quão sensata soa esta declaração e, no entanto, quão equivocada ela certamente é. Se os símbolos religiosos são entendidos, a partir da analogia com as palavras, como veículos para o significado, podem tais significados ser estabelecidos independentemente das formas de vida nas quais eles são usados? Se os símbolos religiosos devem ser tomados como assinaturas de um texto sagrado, podemos saber o que significam sem considerar as disciplinas sociais através das quais sua leitura correta é assegurada? Se os símbolos religiosos devem ser pensados enquanto conceitos através dos quais as experiências são organizadas, podemos dizer algo sobre eles sem considerar o modo pelo qual vêm a ser autorizados? Mesmo se defendermos que o que é experienciado através dos símbolos religiosos não é, em essência, o mundo social, mas o espiritual ${ }^{37}$, é possível afirmar que as condiçôes no mundo social não têm relação alguma com a produção da acessibilidade desse tipo de experiência? É o conceito de treinamento religioso inteiramente vazio?

Os dois estágios propostos por Geertz são, eu sugeriria, um. Os símbolos religiosos - sejam eles pensados em termos de comunicação ou cognição, como guias para a ação ou para expressar emoção - não podem ser compreendidos independentemente de suas relaçóes históricas com os símbolos não religiosos ou de suas articulaçóes no interior e sobre a vida social, na qual trabalho e poder são sempre cruciais. $\mathrm{O}$ meu argumento, devo enfatizar, não é apenas que símbolos religiosos estão intimamente ligados à vida social (e portanto mudam 
com ela), ou que eles frequentemente apóiam o poder político dominante (e, ocasionalmente, se opóem a ele). É que diferentes tipos de prática e discurso sáo intrínsecos ao campo em que as representaçóes religiosas (como qualquer representação) adquirem sua identidade e sua veracidade. Desta afirmação não se conclui que os significados das práticas e enunciações religiosas devam ser procuradas em fenômenos sociais, mas que sua possibilidade e seu status autoritativo devem ser explicados enquanto produtos de forças e disciplinas historicamente específicas. $\mathrm{O}$ interessado em religióes particulares, de um ponto de vista antropológico, deveria, portanto, partir deste ponto: abrir o conceito abrangente com o qual ele ou ela traduz "religião" em elementos heterogêneos de acordo com suas características históricas.

Uma última palavra de advertência. Os leitores apressados podem concluir que minha discussão sobre a religião cristã tem um viés autoritário, centralizador e elitista, e que consequentemente falha em levar em conta as religióes de fiéis heterodoxos, de camponeses resistentes, de todos aqueles que náo puderam ser completamente controlados pela ortodoxia da igreja. $\mathrm{Ou}$, ainda pior, que minha discussão não tem nenhuma relevância para os cultos não disciplinares e voluntaristas e localizados de religiōes não centralizadas como o hinduísmo. Mas essa conclusão seria uma compreensão equivocada deste texto, considerando-o uma tentativa de defender uma definição antropológica de religiáo melhor do que a fornecida por Geertz. Nada estaria mais distante de minha intenção. Se meus esforços se dirigem, em grande medida, a um breve esboço das transmutaçóes do cristianismo da Idade Média até hoje, isso não se deve ao fato de eu ter confinado meus exemplos etnográficos, de forma arbitrária, a uma religião. $\mathrm{O}$ meu objetivo foi problematizar a ideia de uma definição antropológica da religião ao remeter este esforço a uma história particular do conhecimento e do poder (e isso inclui uma compreensão particular acerca de nosso passado e futuro legítimos) a partir da qual o mundo moderno foi construído ${ }^{38}$.

\section{Notas}

1. Veja-se Fustel de Coulanges (2003). Publicada originalmente em francês em 1864, a obra exerceu influência, historicamente, sobre várias disciplinas que se sobrepunham - antropologia, estudos bíblicos e clássicos.

2. Originalmente publicado em 1966, foi reimpresso em seu aplaudido A interpretação das culturas (1989).

3. Compare com a apresentação mais rigorosa de Peirce de representaçôes: "Uma representação é um objeto que substitui outro, de modo que uma experiência do primeiro nos fornece um conhecimento do segundo. Há três condiçôes essenciais a que toda representaçâo deve obedecer. Em primeiro lugar, ela deve, como qualquer outro objeto, ter qualidades que independem de seu significado. (...) Em segundo lugar, uma representaçáo deve ter um nexo causal real com seu objeto. (...) Em terceiro lugar, toda representação se encaminha para uma mente. É somente ao fazer isso que ela é uma representação" (Peirce, 1986, p. 62).

4. Vigotsky (1962) estabelece distinçôes analíticas cruciais no desenvolvimento do pensamento conceitual: sincretismos, complexos, pseudoconceitos, e conceitos. Embora segundo Vygotsky estes representem estágios no desenvolvimento do uso da linguagem pelas crianças, os primeiros estágios permanecem atuantes na vida adulta.

5. Cf. Collingwood (1938, livro 2) para uma discussão da conexão integral entre pensamento e emoção, onde se argumenta que não existe nada que se assemelhe a uma função emocional universal que acompanha toda conceituação/comunicação: cada atividade cognitiva/comunicativa distintiva elenca uma emoção específica. Caso esta visão seja válida, poder-se-á questionar a noção de uma emoção (ou temperamento) religiosa generalizada.

6. O argumento de que os símbolos organizam a prática e, consequentemente, a estrutura da cognição, é central para a psicologia genética de Vigotsky. Ver, especialmente, "Tool and Symbol in Child Development” (Vigotsky, 1978). Uma concepção cognitiva dos símbolos foi retomada recentemente por Sperber (1975). Uma posiçâo semelhante foi adotada muito antes por Lienhardt (1961). 
7. "A história do processo de internalização da fala social é, também, a história da socialização do intelecto prático das crianças" (Vigotsky, 1978, p. 27). Ver também Luria e Yudovich (1971).

8. N.T.: Em certas passagens do texto, preferimos utilizar o neologismo "autoritativo" para traduzir o adjetivo "authoritative" ou "authorizing". Diferentemente de "autorizado", a expressão de Asad tem a virtude de referir-se tanto à autoridade atribuída a símbolos e práticas considerados legítimos, quanto à autoridade incorporada por estas agências atribuidoras elas mesmas. Nesse sentido, símbolos e práticas autorizados são os produtos de processos autoritativos, apesar de nunca os resumirem ou esgotarem. Um interessante debate sobre a oposição de Asad à antropologia simbólica através da noção de discurso autoritativo encontra-se em Canton (2006) assim como na réplica do próprio autor (Asad, 2006).

9. Ou, como Kroeber e Kluckhohn (1952, p. 181) colocaram anteriormente: "A cultura consiste em padrôes, explícitos ou implícitos, de e para comportamentos adquiridos e transmitidos por símbolos".

10. Se colocarmos de lado a preocupação bem conhecida de Radcliffe-Brown com a coesão social, poderemos nos lembrar que ele também estava interessado em especificar certos tipos de estados psicológicos sobre os quais se diz que são induzidos por símbolos religiosos: "Os ritos podem ser vistos como as expressóes simbólicas moderadas de certos sentimentos. Podem mostrar, portanto, terem função social específica quando, e na medida em que, tenham por efeito refrear, manter e transmitir de uma geraçấo a outra sentimentos dos quais a constituição da sociedade depende" (1973, p. 196).

11. Alguns caminhos pelos quais a simbolização (discurso) pode disfarçar sua falta de distintividade são bem explicitados pela crítica mordaz de MacIntyre aos escritores cristãos contemporâneos, na qual ele argumenta que "os cristãos agem como todos os demais, mas fazem uso de um vocabulário diferenciado para caracterizar seu próprio comportamento, e também para ocultar sua falta de distintividade" (1971, p. 24).

12. $\mathrm{O}$ fenômeno da diminuição da frequência às igrejas na sociedade industrial moderna e sua progressiva marginalização (ao menos na Europa) dentre os setores da população não envolvidos diretamente no processo de trabalho industrial ilustra o argumento de que se formos procurar explicaçôes causais nesta área, as condiçóes socioeconômicas em geral aparecerão como a variável independente, sendo a devoção formal a dependente. Veja a interessante discussão a esse respeito em Luckman (1967, cap 2).
13. N. T.: Os conceitos de Geertz citados por Talal Asad são "moods" e "motivations", o que náo deveria ser traduzido por "disposiçôes" (que é outro conceito, citado anteriormente) e "motivaçôes", como ocorre no texto, mas sim por "estados de espírito" e "motivaçōes". No entanto, na tradução já existente em português (e bastante divulgada nacionalmente), ocorre este equívoco. Considerando o caráter didático de uma tradução cujo objetivo primordial é ampliar o acesso ao texto para os não leitores da língua em que foi originalmente escrito -, optamos por manter o equívoco, assinalando-o, de maneira que os estudantes possam encontrar com maior facilidade as frases de Geertz na tradução brasileira (Geertz, 1989) e verificar se há ou não remoção de contexto ou desvirtuamento de sentido.

14. É por isso que Agostinho acabou por adotar a visão de que a falta de sinceridade na conversão não era um problema (Chadwick, 1967, p. 222-240).

15. Nas palavras de um teólogo moderno: "A diferença entre o modo de falar que professa, proclama e orienta, por um lado, e a fala descritiva, por outro, é às vezes formulada como a diferença entre 'falar sobre' e 'falar para'. Tão logo esses dois modos de fala são confundidos, diz-se que o caráter único e original do discurso religioso é corrompido, de modo que a realidade-como-ela-é-para-o-crente não mais pode 'aparecer' para ele do mesmo modo que aparece na fala que professa" (Luijpen, 1973, p. 90-91).

16. A série de livretos conhecida como Manuais de Penitência, com a ajuda dos quais a disciplina cristã foi imposta na Europa Ocidental aproximadamente do século $\mathrm{V}$ ao $\mathrm{X}$, contém vasto material sobre as práticas pagãs penalizadas por não serem cristãs. Assim, por exemplo, 'São ofensas condenadas a realização ou anulação de votos próximos a fontes, árvores ou gelosias, ou em qualquer lugar que não numa igreja, assim como compartilhar bebida ou comida nesses espaços consagrados a deidades pagãs' (apud McNeill, 1933, p. 456). (Para mais detalhes, ver McNeill e Gammer, 1938). Nesta mesma época, o papa Gregório, o Grande (540-604 d.C.) 'exortava a igreja a ocupar os velhos templos e festivais pagãos de modo a dotá-los de sentido cristáo' (Chadwick, 1967, p. 254). A aparente incoerência entre essas duas atitudes (rejeição ou incorporação de práticas pagãs) é menos importante do que o exercício sistemático de autoridade da Igreja através do qual o sentido era atribuído.

17. "Por um lado, os bispos se queixavam de crenças que eles viam como rudes e por demais ávidas por maravilhas e milagres não autorizados e não devidamente 
examinados, enquanto, por outro lado, os teólogos (possivelmente estes mesmos bispos) tentavam se haver com a questão. Apesar de tentarem definir milagres recorrendo à lei natural universal, tais definições nunca eram inteiramente bem-sucedidas, e em casos específicos, individuais, o senso comum tendia a ser um guia melhor do que a cosmologia medieval. Quando os comissários papais se sentaram para ouvir testemunhos sobre os milagres de Thomas Cantilupe em Londres e Hereford em 1307, depararam-se com uma série de questôes a serem colocadas para dar conta desses eventos extraordinários: eles queriam saber, por exemplo, como a testemunha veio a saber do milagre, quais foram as palavras usadas por aqueles que rezaram pelo milagre, se quaisquer ervas, pedras, outros preparados naturais ou medicinais ou encantamentos haviam acompanhado o desenrolar do milagre; da testemunha se esperava que dissesse algo sobre a idade e a situação social da pessoa que experienciou o milagre, de onde ela veio e de qual família; se a testemunha conhecia o sujeito tanto antes quanto depois do milagre, qual era a doença envolvida, quantos dias antes da cura ela havia visto a pessoa doente; se a cura foi completa e quanto tempo levou para que fosse plenamente realizada. É claro que as testemunhas também eram interrogadas sobre o ano, mês, dia, lugar e na presença de quem o evento extraordinário teria ocorrido" (Finucane, 1977, p. 53).

18. Ao serem autorizados, os santuários, por sua vez, serviam para confirmar a autoridade eclesiástica: "Os bispos da Europa ocidental vieram a orquestrar o culto dos santos de forma a fundamentar o seu poder dentro das antigas cidades romanas nessas 'cidades fora da cidade'. No entanto, foi através de um relacionamento cuidadosamente articulado com os grandes santuários que ficavam a alguma distância da cidade - São Pedro, na montanha do Vaticano, fora de Roma, São Martinho, um pouco depois além dos muros de Tours - que os bispos das primeiras cidades do Império Romano alcançaram proeminência na Alta Idade Média européia” (Brown, 1981, p. 8).

19. A vida de Santo Antônio, por Athanasius, foi o modelo das hagiografias medievais, e a sequência antonina de vida prévia, crise e conversão, provação e tentação, privação e renúncia, poder miraculoso, somados ao conhecimento e à autoridade, foi reproduzida insistentemente por essa literatura (Baker, 1972, p. 41).

20. O Concílio Laterano de 1215 declarou a confissão privada anual obrigatória para todos os cristáos: "Cada $f$ delis de qualquer um dos sexos, após atingir alguns anos de discernimento, deverá confessar seus pecados priva- damente a seu padre com toda fidelidade no mínimo uma vez ao ano: e deverá tentar cumprir a penitência a ele imposta no máximo possível das suas capacidades, recebendo com reverência o sacramento da Eucaristia pelo menos na Páscoa: a menos que a conselho de seu próprio padre e por alguma causa razoável, seja decidido que ele deva se abster da recepçáo deste sacramento temporariamente: caso contrário, que ele seja proibido, durante sua vida, de adentrar uma igreja e, quando morto, que sinta a falta de um enterro cristão. Por conseguinte, que este estatuto salutar seja frequentemente publicado nas igrejas, de modo que ninguém encontre o véu da isençấo na cegueira da ignorância" (apud Watkins, 1920, p. 748-49).

21. Para uma breve introdução às várias reações das autoridades eclesiásticas aos franciscanos e beguinas, veja-se Southern, 1970, caps. 6 e 7. "Beguinas" era o nome dado aos grupos de mulheres celibatárias, dedicadas à vida religiosas, mas que não deviam obediência à autoridade eclesiástica. Floresceram nos povoados da Alemanha ocidental e nos Países Baixos, mas foram criticadas, denunciadas e finalmente suprimidas no início do século XV.

22. Assim, Cipriano: "Se um homem não se atém a esta unidade da Igreja, pode ele crer que se atém à fé? Se um homem recusa e resiste à Igreja, pode ele confiar que está na Igreja? Pois o abençoado apóstolo Paulo prega o mesmo ensinamento, e estabelece o sacramento da unidade, ao afirmar: 'Há apenas um corpo, um Espírito, uma esperança em nosso chamado, um Mestre, uma fé, um batismo, um Deus'. Esta unidade nós devemos firmemente defender, e a ela nos atermos, especialmente nós, que presidimos a Igreja enquanto bispos, cujo dever é promover um episcopado que em si também é uno e indiviso. Que ninguém engane nossos irmãos através da falsidade, que ninguém corrompa a verdade de nossa fé através de transgressōes infiéis" (apud Bettenson, 1956, p. 264).

23. A Igreja sempre exerceu a autoridade de ler a prática cristã de acordo com sua verdade religiosa. Nesse contexto, é interessante notar que a palavra heresia inicialmente designava todo tipo de erro, inclusive erros "inconscientemente" envolvidos em alguma atividade (simoniaca haersis), tendo adquirido seu sentido especificamente moderno (a formulação verbal da negação ou dúvida acerca de qualquer doutrina definida da igreja católica) apenas no decurso das controvérsias metodológicas do século XVI (Chenu, 1968, p. 276).

24. Na Baixa Idade Média, a disciplina monástica foi a principal base da religiosidade. Knowles (1963, p. 3) observa que aproximadamente do século VI ao XII "a 
vida monástica baseada na Regra de São Bento era por toda a parte a norma e exercia de tempos em tempos uma grandiosa influência na vida espiritual, intelectual, litúrgica e apostólica da Igreja Ocidental. (...) o único tipo de vida religiosa disponível nos países em questão era a vida monástica, e o único código monástico era a Regra de São Bento”. Durante este período, o próprio termo religioso era, portanto, reservado para aqueles que viviam em comunidades monásticas; com a emergência tardia de ordens não monásticas, o termo veio a ser utilizado de modo a também englobar todos aqueles que haviam feito votos vitalícios, pelos quais eram diferenciados dos membros ordinários da Igreja (Southern, 1970, p. 214). A extensão e simultânea transformaçáo das disciplinas religiosas para os setores laicos da sociedade do século XII em diante (Chenu, 1968) contribuiu para que a autoridade da Igreja se tornasse mais disseminada, mais complexa e também mais contraditória do que antes - o mesmo valendo para a articulação entre o conceito e a prática da religião laica.

25. Logo, permitindo ao antropólogo Vitoriano e estudioso da Bíblia Robertson Smith afirmar que, na era da historiografia científica, "não serão mais os resultados da teologia que seremos instados a defender, mas algo anterior à teologia. $\mathrm{O}$ que teremos que defender não será nosso conhecimento cristão, mas nossa crença cristã” (1912, p.110). Não se espera que a crença cristã se estabeleça através da Bíblia enquanto revelação divina, mas sim enquanto "o registro da revelação divina - o registro dos fatos históricos através dos quais Deus revelou-se aos homens" (1912, p. 123). Portanto, os princípios da interpretação histórica não eram mais estritamente cristãos; apenas as crenças às quais estas interpretaçôes serviram.

26. Quando missionários cristáos se encontraram em territórios culturalmente estranhos, o problema da identificação da "religião" tornou-se uma questão de considerável dificuldade teórica e importância prática. Por exemplo, "Os jesuítas na China consideravam que a reverência aos ancestrais era um ato social, não religioso, ou que, se fosse religioso, seria pouco diferente das preces católicas endereçadas aos mortos. Eles desejavam que os chineses percebessem o cristianismo não como um substituto, não como uma nova religião, mas como a mais plena realização de suas aspiraçôes mais refinadas. Mas a seus oponentes os jesuítas pareciam simplesmente relapsos. Em 1631, um franciscano e um dominicano da zona espanhola de Manila viajaram (ilegalmente, do ponto de vista português) para Pequim e descobriram que, para traduzir a palavra missa, o catecismo je- suíta utilizava a palavra tsi, que era a descrição chinesa das cerimônias de culto aos ancestrais. Uma noite eles compareceram disfarçados à tal cerimônia, observaram a participação de chineses cristãos e ficaram escandalizados com o que viram. Assim teve início a longa querela acerca dos "ritos", que assolou as missóes orientais por um ou mais séculos" (Chadwick, 1964, p. 338).

27. Veja-se, por exemplo, o capítulo sobre "animismo" na parte 2 de Primitive Cultures, de Tylor (1871).

28. As fases do gradual esvaziamento da especificidade dos discursos religiosos públicos ao longo do século XVIII são descritas com algum detalhe em Gay (1973).

29. A maneira pela qual as representaçôes de ocorrências foram transformadas em significados pela teologia Cristã é analisada por Auerbach em seu estudo clássico sobre a representaçáo da realidade na literatura Ocidental e brevemente resumida na seguinte passagem: "Todo o conteúdo das Sagradas Escrituras foi colocado num contexto exegético, que freqüentemente afastava muito o acontecimento relatado de sua base sensorial, enquanto obrigava o leitor ou ouvinte a desviar sua atenção do acontecimento sensível, para concentrá-la no seu significado. Isto implicava, portanto, a possibilidade de que o visual dos acontecimentos ficasse paralisado e sufocado pelo denso emaranhado dos significados. Eis um exemplo, dentre muitos: Deus cria a primeira mulher, Eva, da costela de Adão adormecido: trata-se de um acontecimento visualmente dramático; o mesmo vale para o momento em que um soldado crava a lança no corpo de Jesus, morto na cruz, de modo a fazer fluir sangue e água. Contudo ambos os episódios são postos em correlação mediante a exegese, ensinando que o sono de Adão é uma imagem do sono mortal de Cristo, e que assim como da ferida no flanco de Adáo nasce a máe primordial da humanidade segundo a carne, Eva, do mesmo modo, da ferida no flanco de Cristo nasce a mãe dos vivos segundo o espírito, a Igreja - sangue e água são símbolos sacramentais -, o acontecimento sensorial empalidece, sobrepujada pela significaçâo apurada.O que o leitor ou ouvinte (...) incorporam a si mesmos é frágil quanto à impressáo sensorial; todo o seu interesse vê-se dirigido para a conexão significativa . Frente a isso, as representaçóes realistas greco-latinas não são tấo sérias e problemáticas, e muito mais limitadas na sua captação dos movimentos históricos; mas estâo asseguradas na sua substância sensória; desconhecem a luta entre aparência sensível e significação, luta que permeia a visão da realidade dos primeiros tempos do Cristianismo e, a bem dizer, de todo o Cristianismo" (2004, p. 41-42). Como Auerbach segue demons-

cadernos de campo, São Paulo, n. 19, p. 263-284, 2010 
trando, a teoria cristã da Baixa Idade Média investiu as representações da vida cotidiana sentidos figurativos característicos, e portanto com possibilidades para tipos específicos de experiência religiosa. A interpretação figurativa, de acordo com Auerbach, não é sinônimo de simbolismo. O último está mais próximo da alegoria, na qual o símbolo é substituído pelo objeto simbolizado. Na interpretação figurativa, a representação de um evento (o sono de Adão) torna-se explícita através da representação de outro evento (a morte de Cristo), que é seu significado. A última representação completa a primeira (o termo técnico, Auerbach nos conta, é $f$ guram implire) - está implícita nele.

30. Cf. Douglas (1975, p. 76): "A pessoa sem religião seria a pessoa satisfeita em agir sem explicaçôes de certos tipos, ou satisfeita em se comportar na sociedade na ausência de um princípio unificador que valide a ordem social".

31. Quando o bispo de Javols do século V disseminou o cristianismo em Auvergne, encontrou os camponeses "celebrando um festival de três dias, que incluía oferendas feitas nos limites de um pântano (...) 'Nulla est religio in stagno', disse ele: Não pode haver religião em um pântano" (Brown, 1981, p. 125). Para os cristãos medievais, a religião não era um fenômeno universal: ela era o lugar no interior do qual a verdade universal era produzida, e era claro para eles que a verdade náo era produzida universalmente.

32. Como coloca um teólogo católico contemporâneo: "O desafio secularista, apesar de separar vários aspectos da vida do campo religioso traz com ele um equilíbrio interpretativo mais sólido: os fenômenos naturais, embora às vezes difíceis de serem entendidos, têm sua causa e raízes em processos que podem e devem ser reconhecidos. É trabalho do homem, portanto, adentrar esta análise cognitiva do significado do sofrimento com o propósito de tornar-se mais apto a enfrentá-lo e a conquistá-lo. A condição contemporânea do homem, daquele que crê às beiras do terceiro milênio, é sem dúvida mais adulta $\mathrm{e}$ madura e permite uma nova abordagem para o problema do sofrimento humano" (Autiero, 1987, p. 124).

33. N.T.: Tentei descrever um dos aspectos deste processo em Asad (1986).

34. As tentativas filosóficas de definir a ciência não atingiram um consenso. No mundo anglo-saxáo, os argumentos recentes têm sido formulados em torno dos trabalhos de Popper, Kuhn, Lakatos, Feyerabend, Hacking e outros; na França, em torno dos argumentos de Bachelard e Canguilhem. Uma tendência importante tem sido o abandono da tentativa de resolver o que nes- sa literatura é conhecido como o problema da demarcação, que se baseia na suposição de que deveria haver um método científico único e essencial. A ideia de que o cientista "dissolve o caráter dado do mundo em um turbilhão de hipóteses probabilísticas" é tão questionável quanto a sugestão complementar de que na religiâo não haveria espaço para a experimentação. Sobre este último aspecto, há muitas evidências de experimentos mesmo se nos ativermos apenas à história do ascetismo cristão. Igualmente, a sugestão de que a arte é uma questáo de "se descomprometer em relação a toda a questão da facticidade, manufaturando deliberadamente um ar de semelhança e ilusão" não seria tomada como autoevidente por todos os escritores e artistas. Por exemplo, quando o crítico de arte John Berger argumenta, em seu brilhante ensaio "The Moment of Cubism", que o cubismo "mudou a natureza da relação entre a imagem pintada e a realidade, e ao fazê-lo expressou uma nova relação entre o homem e a realidade" (1972, p. 145), aprendemos algo sobre a preocupação do cubismo com a redefinição da facticidade visual.

35. Caso alguns leitores estejam tentados a pensar que o objeto sobre o qual estou falando não é a ciência (teoria), mas a tecnologia (aplicação prática), enquanto Geertz estaria preocupado apenas com a primeira, eu destacaria que as tentativas de fazer uma distinçấo clara entre esses dois campos baseia-se em uma visão excessivamente simplificada da prática histórica de ambas (cf. Musson; Robinson, 1969). Meu argumento é de que a ciência e a tecnologia juntas são fundamentais para a estrutura das vidas modernas, individuais e coletivas, e que a religião, em qualquer sentido que não o mais vazio, não é.

36. Na introdução a sua coleçấo de ensaios de 1983 , Geertz (1997) parece querer abandonar essa abordagem perspectivista: "Quando nos voltamos para a arte, essas questôes tornam-se ainda mais oportunas, porque, mesmo se comparado a debates em torno de temas como 'religiāo', 'ciência', 'ideologia' ou 'direitos', a discussão sobre se a arte é ou não uma categoria adequada em contextos 'não-ocidentais' ou 'pré-modernos' vem sendo peculiarmente inflexível. E tem sido também peculiarmente improdutiva. Seja qual for o nome que se queira dar a uma parede de caverna coberta de imagens sobrepostas de animais transfixados, a uma torre de um templo que termina na forma de um falo, a um escudo de penas, a um pergaminho caligráfico, ou a um rosto tatuado, afinal, o que temos é um fenômeno a ser considerado, e talvez também uma sensação de que, se acrescentarmos à lista o sistema de 
A CONSTRUÇÃo DA RELIGIÃo COMO UMA CATEGORIA ANTROPOLÓGICA $\mid 283$

intercâmbio kula, ou o livro do Juízo Final, a série já não estaria correta. Não se trata de saber se a arte (ou qualquer outra coisa) é ou não universal, e sim se podemos falar sobre escultura africana ocidental, pintura em folhas de palmeira da Nova Guiné, quadros do Quatrocentos, ou versos marroquinos, de uma forma tal que a descrição de cada um destes fenômenos possa contribuir para tornar os outros mais claros" (1997, p. 22 ênfase adicionada). A resposta para esta questão deve certamente ser: sim, é claro que se deve tentar falar sobre coisas distintas umas em relação às outras, mas qual é exatamente o propósito de construir uma série cujos itens podem ser facilmente reconhecidos por ocidentais cultivados como exemplos do fenômeno da arte? É claro que uma coisa pode iluminar outra. Mas não é precisamente quando alguém abandona as perspectivas convencionais ou as séries preestabelecidas em favor de comparaçóes oportunas que a iluminação (em oposição ao reconhecimento) pode ser alcançada? Tomemos como exemplo o esplêndido livro de Hofstadter, Gödel, Escher, Bach (1979).

37. Veja-se o capítulo final de Evans-Pritchard (1956) e a conclusão de Evans-Pritchard (1965).

38. Esses esforços são incessantes. Como um estudo recente e estimulante de Tambiah (1990, p. 6) coloca, logo no primeiro capítulo: "Na discussão que se segue, eu tentarei argumentar que, a partir de um ponto de vista antropológico geral, a característica específica da religião como um conceito genérico jaz não no domínio da crença e de sua 'explicação racional' do funcionamento do universo, mas em uma consciência especial do transcendente e dos atos de comunicaçáo simbólica que tentam realizar essa consciência e viver de acordo com seus estímulos".

\section{Referências bibliográficas}

ASAD, Talal. Medieval heresy: an anthropological view. Social History, v. 11, no.3, p. 345-362, 1986.

Responses. In: SCOTT, D; HIRS-

CHKIND, C. (Orgs.). Powers of the Secular Modern: Talal Asad and his Interlocutors. Stanford: Stanford University Press, 2006, p. 206-242.

AUERBACH, Erich. Mimesis: a Representação da Realidade na Literatura Ocidental. São Paulo: Perspectiva, [1946] 2004.

AUTIERO, Antonio. The interpretation of pain: the point of view of Catholic theology. In: BRIHAYE, J et al. (Org.). Pain: a Medical and Anthropological Challenge. New York: Springer-Verlag, 1987, p. 123-126.
BAKER, Derek. Vir Dei: a Secular Sanctity in the Early Tenth Century. In: CUMING, C. J; BAKER, D. (Orgs.). Popular Belief and Practice. Cambridge: Cambridge University Press, 1972, p. $41-54$.

BETTENSON, Henry (Org.). The Early Christian Fathers: a Selection from the Writings of the Fathers from St Clement of Rome to St Athanasius . London: Oxford University Press, 1956.

BERGER, John. Selected Essays and Articles. Harmonsworth, Middlesex: Penguin, 1972.

BROWN, Peter. Santo Agostinho: uma biografia. Rio de Janeiro: Record, [1967] 2005.

The Cult of the Saints: its Rise and Function in Latin Christianity. London: SCM, 1981.

CANTON, Steven. What is an authorizing discourse? In: SCOTT, D; HIRSCHKIND, C (Orgs.). Powers of the Secular Modern: Talal Asad and his Interlocutors. Stanford, CA: Stanford University Press, 2006, p. 31-56.

CHADWICK, Henry. The Early Church. Harmondsworth, Middlesex: Penguin, 1967.

CHADWICK, Owen. The Reformation. Harmondsworth, Middlesex: Penguin, 1964

CHENU, Marie D. Nature, Man, and Society in the Twelfth Century: Essays on Theological Perspective in the Latin West. Chicago: University of Chicago Press, 1968.

COLLINGWOOD, Robin G. The principles of Art. London: Oxford University Press, 1938.

COUlANGES, Fustel de. A cidade antiga. São Paulo: Ediouro, [1864] 2003.

DOUGLAS, Mary. Implicit Meanings. London: Routledge and Kegan Paul, 1975.

DUMONT, Louis. Religion, politics, and society in the individualistic universe (The Henry Myers Lecture). Proceedings of the Royal Anthropological Institute for Great Britain and Ireland, 1970. London: Royal Anthropological Institute, 1971, p. 31-41.

EVANS-PRITCHARD, Edward. E. Nuer religion. Oxford: Claredon, 1956.

Theories of primitive religion. Oxford: Claredon, 1965.

FINUCANE, Ronald. C. Miracles and Pilgrims: Popular Beliefs in Medieval England. London: Dent, 1977.

GAY, Peter. The Enlightenment: An Interpretation. 2 vols. London: Wildwood House, 1973.

GEERTZ, Clifford. A religião como sistema cultural. In: A Interpretação das Culturas. Rio de Janeiro: LTC, [1973] 1989.

- O Saber Local: Novos Ensaios em Antropologia Interpretativa. Petrópolis, RJ: Vozes, [1983] 1997.

cadernos de campo, São Paulo, n. 19, p. 263-284, 2010 
284 TALAL AsAD

HARRÉ, R. Psychological variety. In: HEELAS, P; LOCK, A (Orgs.). Indigenous Psychologies: the Anthropology of the Self. London: Academic Press, 1981.

HOFSTADTER, Douglas. Gödel, Escher, Bach: An Eternal Golden Braid. New York: Basic Books, 1979.

KANT, Immanuel. A Paz Perpétua e Outros Opúsculos. Lisboa, Portugal: Edições 70, [1795] 2009.

KNOWLES, David. The Monastic Order in England: $940-$ 1216. Cambridge: Cambridge University Press, 1963.

KROEBER, Alfred. L. \& KLUCKHOHN, Clyde. Culture: a critical review of concepts and definitions. $\mathrm{Pa}$ pers of the Peabody Museum, v. 47, n 1. Cambridge: Peabody Museum, 1952.

LIENHARDT, Geoffrey. Divinity and Experience. Oxford: Clarendon, 1961.

LUCKMAN, Thomas. The Invisible Religion. New York: Macmillan, 1967.

LUIJPEN, William A. Theology as Anthropology. Pittsburgh: Duquesne University Press, 1973.

LURIA, Alexander R. \& YUDOVICH, F. I. Speech and Development of Mental Processes in the Child. Harmondsworth, Middlesex: Penguim, 1971.

MACINTYRE, Alasdair. Against the Self-Images of the Age. London: Duckworth, 1971.

MACNEILL, John. T. Folk-paganism in the penitentials. Journal of Religion, v. 13, no.4, 1933, p. 45-466.

MACNEILL, John T.; GAMER, Helena. M. (Orgs.) Medieval Handbook of Penance. New York: Columbia University Press, 1938.
MUSSON, Albert. R.; ROBINSON, Eric. Science and Technology in the Industrial Revolution. Manchester: Manchester University Press, 1969.

NEEDHAM, Rodney. Belief, Language, and Experience. Oxford: Basil Blackwell, 1972.

PEIRCE, Charles S. Writings of C. S. Peirce. Vol. 3. Bloomington: Indiana University Press, 1986.

RADCLIFFE-BROWN, Alfred. R. Religião e Sociedade. In: Estrutura e função na sociedade primitiva. Petrópolis, RJ: Vozes, [1952] 1973. p. 191-219.

SOUTHERN, Richard. W. Western Society and the Church in the Middle Ages. Harmondsworth, Middlesex: Penguin, 1970.

SOUTHWOLD, Martin. Religious Belief. Man. n. 14., 1979, p. 628-644.

SPERBER, Dan. Rethinking Symbolism. Cambridge: Cambridge University Press, 1975.

SMITH, William R. Lectures of William Robertson Smith. BLACK, J. S; CHRYSTAL, G (Eds.). London: A. and C. Black, 1912.

TAMBIAH, Stanley. J. Magic, science, Religion and the Scope of Rationality. Cambridge: Cambridge University Press, 1990.

TYLOR, Edward. B. Primitive Culture. London: J. Murray, 1971.

VIGOTSKY, Lev S. Thought and Language. Cambridge: MIT Press, [1934] 1962.

. Mind in Society. Cambridge: Harvard University Press, 1978.

WATKINS, Oscar. D. A History of Penance. 2 vols. London: Longmans, 1920.

\section{traduzido de}

ASAD, Talal. Genealogies of Religion. pp. 27-54. (C) 1993 The Johns Hopkins

University Press. Translated with permission of The Johns Hopkins University Press.

\section{tradutor Eduardo Dullo}

Doutorando em Antropologia Social / MN-UFRJ

tradutor Bruno Reinhardt

Doutorando em Antropologia Social / UC Berkeley

Recebida em 15/06/2010

Aceita para publicação em 15/06/2010

cadernos de campo, São Paulo, n. 19, p. 263-284, 2010 